\title{
CHARACTERIZATION OF THE VADOSE FLOW AND ITS INFLUENCE ON THE FUNCTIONING OF KARST SPRINGS: CASE STUDY OF THE KARST SYSTEM NEAR POSTOJNA, SLOVENIA
}

\author{
ŠTUDIJ ZNAČILNOSTI VADOZNEGA TOKA IN NJEGOVEGA \\ VPLIVA NA DELOVANJE KRAŠKIH IZVIROV: PRIMER KRAŠKEGA \\ SISTEMA PRI POSTOJNI, SLOVENIJA
}

\author{
Janja KOGOVŠEK ${ }^{1} \&$ Metka PETRIČ $^{1}$
}

\begin{abstract}
UDC 556.322:551.444(497.4)

Janja Kogovšek \& Metka Petrič: Characterization of the vadose flow and its influence on the functioning of karst springs: Case study of the karst system near Postojna, Slovenia

In three selected drips in the Postojna cave in SW Slovenia and in the nearby Korentan spring, which in general belongs to the same karst aquifer, the discharge and electrical conductivity were measured at 15-minute intervals. Simultaneously, the meteorological parameters in Postojna were measured and the effective infiltration was assessed. The data obtained in the period of one hydrological year, 2003-2004, was compared in order to study the influence of the vadose flow on the characteristics of groundwater flow in a karst system and on the functioning of a karst spring. The highest discharges of the Korentan spring are the result of the inflow of water through a hierarchy of fissures of various permeabilities within the vadose zone, but the contribution of stored water from low-permeability zones is especially important. One of our most significant findings is that in the conditions of high saturation of the vadose zone, the network of small fissures is hydraulically connected, which enables an integral reaction of the system to the pressure pulse induced by infiltrated precipitation. On the other hand, a detailed comparison of effective infiltration and discharge indicates that in dry periods with a lower saturation of the vadose zone, the infiltrated precipitation is mainly stored in the system and only the most permeable fissures enable a rapid transfer of the recharge impulses toward the spring. Data on measured discharge and conductivity were additionally compared in order to study the complex conditions of the actual mass flow of water through the system.
\end{abstract}

Key words: karst aquifer, vadose zone, Postojna Cave, Korentan spring, Slovenia.
Izvleček

UDK 556.322:551.444(497.4)

Janja Kogovšek \& Metka Petrič: Študij značilnosti vadoznega toka in njegovega vpliva na delovanje kraških izvirov: primer kraškega sistema pri Postojni, Slovenija

$\mathrm{V}$ treh izbranih curkih v Postojnski jami v JZ Sloveniji in v bližnjem izviru Korentan, ki generalno gledano pripada istemu kraškemu vodonosniku, smo v 15-minutnih intervalih merili pretok in specifično električno prevodnost. Istočasno so bili merjeni meteorološki parametri v Postojni in ocenjene vrednosti efektivne infiltracije. Na osnovi primerjave pridobljenih podatkov za obdobje hidrološkega leta 2003-2004 smo proučevali vpliv vadozne cone na značilnosti toka podzemne vode $\mathrm{v}$ krasu in na delovanje kraškega izvira. Najvišji pretoki izvira Korentan so posledica pretakanja vode v vadozni coni skozi sistem razpok $\mathrm{z}$ različno prepustnostjo, še posebej pomemben pa je prispevek vode iz con zelo slabe prepustnosti. Ena najpomembnejših ugotovitev je, da je v razmerah, ko je vadozna cona dobro namočena, mreža drobnih razpok hidravlično povezana. To omogoča celostno reakcijo sistema na tlačni pulz, ki ga ustvarijo infiltrirane padavine. Po drugi strani pa je podrobna primerjava efektivne infiltracije in pretokov pokazala, da se v sušnih obdobjih z nizko stopnjo zasičenosti vadozne cone pretežni delež infiltriranih padavin uskladišči v sistemu in samo najbolj prepustne razpoke omogočajo hiter prenos impulza napajanja proti izviru. Poleg tega smo s primerjavo merjenih pretokov in specifične električne prevodnosti analizirali razmere dejanskega masnega toka vode skozi kraški sistem.

Ključne besede: kraški vodonosnik, vadozna cona, Postojnska jama, izvir Korentan, Slovenija.

\footnotetext{
${ }^{1}$ Karst Research Institute ZRC SAZU, Titov trg 2, SI-6230 Postojna, Slovenia, e-mails: kogovsek@zrc-sazu.si, petric@zrc-sazu.si. Received/Prejeto: 5.8.2011
} 


\section{INTRODUCTION}

Karst aquifers are highly heterogeneous and their functioning is not easy to characterize. The soil layer represents the upper part of the vadose (unsaturated) zone, within which the rainfall may, depending on the thickness and hydrological properties of the soil, be temporarily stored and then percolate down into the epikarst zone. The epikarst is the upper part of karst rock that is more densely fissured due to the higher aggressiveness of water, tension release, tectonic processes, and variations in temperature. Its principal characteristics are substantial storage capacity and high permeability (Mangin 1975; Williams 1983). Infiltrated water, which can be temporarily stored within it, slowly recharges the low-permeability parts of the vadose zone; however, it may also flow rapidly along preferential flow paths in the vadose zone toward the phreatic (saturated) zone.

In Swiss Jura at the Milandre test site, various research methods were used and one of the findings was that approximately one half of the infiltrated precipitation flows rapidly along preferential flow paths while the other half infiltrates through the low-permeability parts of the aquifer (Jeannin \& Grasso 1995). By isotopic analyses it was proved that although the spring discharge reacts quickly, the majority of freshly infiltrated precipitation accumulates in the system and pushes out the water stored during previous precipitation events (Perrin et al. 2003). Isotopic studies of precipitation and percolated water in the Planina Cave in SW Slovenia established an important homogenization in the vadose zone (Pezdič et al. 1984). Similar conclusions were drawn from research done on several other karst systems using various research methods, mostly tracing with natural and artificial tracers (Stichler et al. 1997; Čenčur Curk et al. 2001; Maloszewski et al. 2002; Trček 2007; Mudarra \& Andreo 2010). Bakalowicz (1995) concluded that the piston effect and the transit of individual molecules of water through the system should be distinguished. Infiltrated water increases the hydraulic head in the epikarst zone and initiates a pressure pulse that stimulates a transfer of water ("pulse-through"). This process is faster than the actual mass flow of water through the system ("flow-through").

Due to the underground nature of flow in karst regions, studies are often limited to the comparison of in- put (precipitation, effective infiltration, discharge of sinking streams) - output (discharge) relationships (Jukić \& Denić-Jukić 2008; Bonacci \& Andrić 2010; Jemcov \& Petrič 2010; Kovačič 2010). However, some important additional information can be obtained from observations in karst caves, which provide a natural way to enter a karst aquifer. The characteristics of the vadose flow can be studied by monitoring dripwater in karst caves (Baker et al. 1997; Vokal et al. 1999; Fairchild et al. 2006; Fernandez-Cortes et al. 2007; Groves 2007, McDonald \& Drysdale 2007; Lange et al. 2010; Miorandi et al. 2010).

In the Slovene karst we began periodical observations of dripwater in caves in 1976 (Kogovšek \& Habič 1981). Through the years the monitoring equipment has become better and the sampling interval shorter, which has enabled more accurate and detailed studies. In recent years, our main research has been concentrated on a study site in Postojna Cave in southwestern Slovenia. Dripwater was observed in several drips in one of its passages, and detailed monitoring has been performed here since 2002 (Kogovšek 2010). While the main emphasis has been on measuring physical and chemical parameters, in addition several tracer tests were carried out in past years (Kogovšek 1997, 2000; Kogovšek \& Šebela 2004; Kogovšek \& Urbanc 2007). In the research described in this article the results of the comparison of discharge (Q) and electrical conductivity (EC) of three selected drips are discussed. These three monitoring points were selected because they differ significantly in their hydrological characteristics. In this way different types of flow through the vadose zone can be observed and compared.

A step further in the research is the comparison of conditions within the vadose zone with precipitation and effective infiltration as input functions of the karst system and with the spring discharge as the output function. The data describing the functioning of a karst spring was obtained through a simultaneous monitoring of the Korentan spring near Postojna, which in general belongs to the same karst aquifer as the Postojna Cave system. The purpose of the research was to study how the percolating water reacts to precipitation events, to characterize the vadose flow, and to assess its influence on the functioning of karst springs.

\section{STUDY AREA}

In the study area (Fig. 1) karstified and well permeable Upper Cretaceous limestone prevails (Buser et al. 1967).
In the Postojna basin it is covered by a relatively thin layer of very poorly permeable Eocene flysch, on which 
the surface drainage network of the Pivka River has developed. Southwest of Postojna the Korentan spring emerges at the northern edge of the karst area of Upper Cretaceous and partly Paleocene limestone at the contact with Eocene flysch. Based on the results of tracer tests (Gospodarič et al. 1970), the known geological conditions, and the hydrological balance, the extent of its recharge area was estimated to be $5.8 \mathrm{~km}^{2}$ (Petrič \& Šebela 2004). Approximately $0.2 \mathrm{~km}^{2}$ of this area is the flysch catchment of the intermittent sinking Čermelice stream, and the rest is a karst aquifer. The Korentan spring is a typical karst spring, characterized by rapid, sharp responses to precipitation events. Spring discharge ranges from a few $1 / \mathrm{s}$ to about $3 \mathrm{~m}^{3} / \mathrm{s}$ with an average of $0.2 \mathrm{~m}^{3} / \mathrm{s}$.

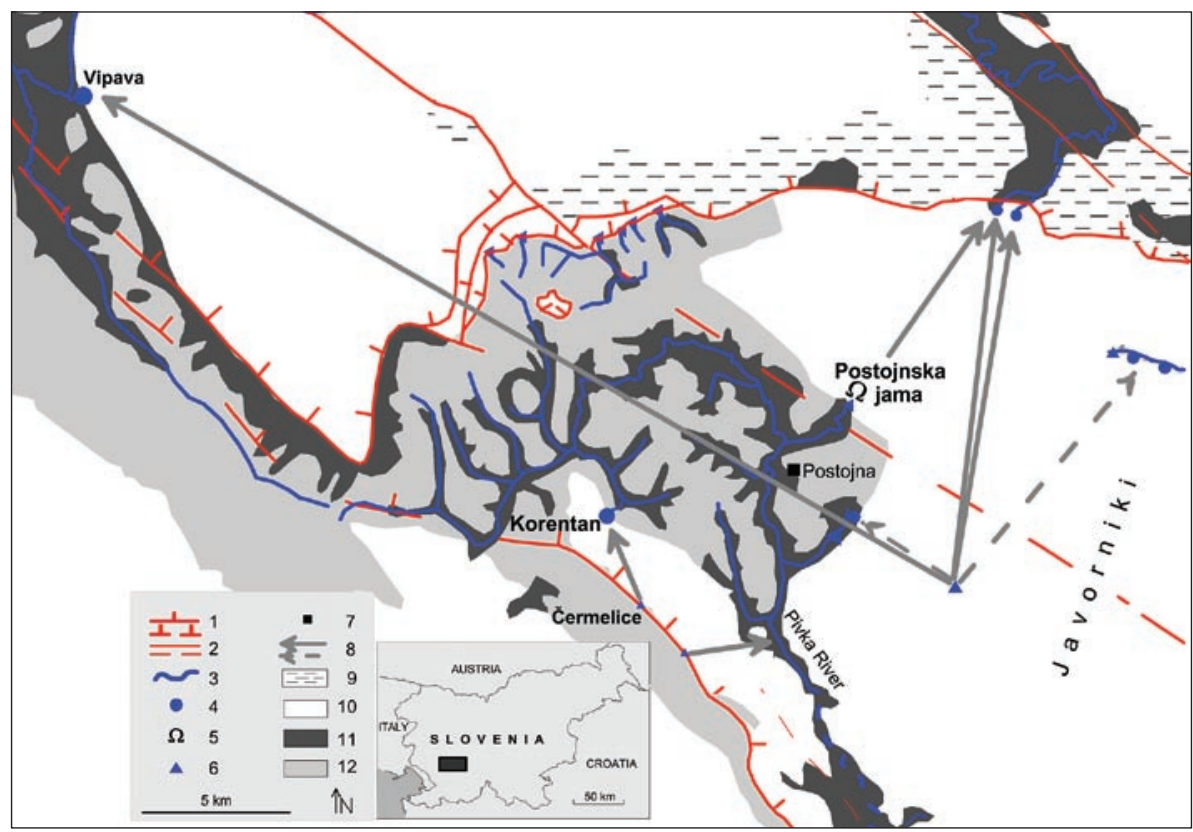

Fig. 1: Hydrogeological map of the Postojna area.

(Legend: 1.Visible and covered thrust plane, 2. Visible and covered fault, 3. Surface stream, 4. Spring, 5. Karst cave, 6. Ponor or injection point, 7. Meteorological station, 8. Main and secondary underground water connection, proved by tracer test, 9. Fissured aquifer, 10. Karst aquifer, 11. Porous aquifer, 12. Very low permeable rocks).

The Postojna Cave, with a total length of $20.6 \mathrm{~km}$, is situated at the other side of the Postojna flysch basin where the Pivka River sinks underground at the contact with carbonate rock. The dripwater was monitored in the Kristalni rov passage, which is a shorter gallery in the initial part of the cave system. This passage with a hundred-meter-thick ceiling formed in Upper Cretaceous thick-bedded limestone. During a previous study, the passage and the surface above were mapped and a detailed structural-lithological 1:1,000 scale map was compiled. The layers of limestone are 0.5 to 1 meter thick. Broken and fissured zones predominate in the passage; their main trend is Dinaric (NW-SE) and they are mostly subvertical (Kogovšek \& Šebela 2004).

In recent years, several drips in the passage have been occasionally observed and their basic hydrological characteristics defined. Based on these preliminary findings, three of the most representative drips (labelled I, J, and L) with different hydrological characteristics were selected for more detailed analysis. According to the structural mapping, the fastest percolation (drip I) occurs in tectonically fissured to moderately broken zones, while slower percolation flows along tectonically broken zones (drip J) and bedding planes (drip L) (Kogovšek \& Šebela 2004). In 2002, continuous, long-term monitoring employing various research methods was initiated on the selected drips. In this way it has been possible to follow the dynamics of the vadose flow and storage, which can be overlooked and misinterpreted using occasional, even though frequent observations. The length of the monitoring period allowed us to understand the functioning in the time frame of hydrological years, and the frequency of measurements at 15-minute intervals the functioning within individual water pulses in the hydrographs that follow more intensive precipitation events.

\section{FIELD MEASUREMENTS}

For two hydrological years, 2003-2004 and 2004-2005, meteorological data (precipitation at 15-minutes inter- vals, and daily values of precipitation, mean air temperature, relative air humidity, wind velocity, sunshine 
hours, and snow depth) from the Postojna meteorological station was obtained from the Environmental Agency of the Republic of Slovenia. To measure precipitation at 15-minute intervals, an Onset RG2-M rain gauge was installed on the surface above the Kristalni rov passage in October 2004. Such data for the entire 2003-2004 hydrological year is not available, but data for the period from October 2004 to December 2005 was used for the comparison of the precipitation regimes at the two locations (Postojna meteorological station, surface above Kristalni rov). With only few exceptions, the precipitation events were recorded on the same days, and the differences between the measured amounts were very small $\left(\mathrm{R}^{2}=0.91\right)$. We therefore decided to consider the meteorological data from the Postojna meteorological station as representative for the recharge areas of the Korentan spring and the dripwater of Kristalni rov.

At the Korentan spring an ISCO 6700 automatic sampler with the YSI600 sonde and the 750 Area-Velocity Module was used to measure EC and water levels at 15-minute intervals. Additionally, Q of the Korentan spring was occasionally measured with an OTT C20 cur- rent meter under different hydrological conditions. The correlation with measured water levels was defined (19 measurements, $\mathrm{R}^{2}=0.99$ ) and used for the calculation of $\mathrm{Q}$ at 15-minute intervals for the whole observation period. During selected water pulses, samples were taken for chemical analysis. Standard methods (Standard Methods for Examination of Water and Wastewater 1992) were used in our laboratory to define total hardness and the concentrations of carbonates, calcium, chlorides, nitrates, sulfates, and o-phosphates.

In the Kristalni rov passage a measurement system was installed at each of the three selected drips (Gealog S Logotronic data-logger and WTW sondes at drips I and $\mathrm{J}$, and an evaporimeter with a mechanical clock at drip L). For drips I and J data on Q and EC, and for drip $\mathrm{L}$ only data on $\mathrm{Q}$ at 15-minute intervals covering more than six hydrological years is now available. Due to very low discharges of drip L (Tab. 1) the precipitation of calcium carbonate is more abundant. Therefore the EC measurements with the normal probe are not representative. As we did not have at our disposal a micro-probe, the EC of drip L was not measured.

\section{COMPARISON OF EFFECTIVE INFILTRATION AND DISCHARGE}

In order to separate various processes in air, vegetation and soil and their influence on the infiltration from the processes within the karst aquifer system, the effective infiltration was assessed first. This parameter describes the amount of water that enters the karst aquifer. The effective infiltration model is based upon the soil water balance. In this method, the sources of water are precipitation reduced by the amount of water intercepted by the vegetation cover, and the amount of water that flows out of the snow cover during melting under suitable climatic conditions. The consumption of water is primarily linked to evapotranspiration. The relationship between the source and the consumption is influenced by the hydrological characteristics of soil. These define the amount of water storage in the soil and

Tab. 1: Characteristic parameters of hydrographs of the Korentan spring and the drips in the Kristalni rov passage, and effective infiltration for the 2003-2004 hydrological year.

\begin{tabular}{|c|c|c|c|c|}
\hline & Drip I & Drip J & Drip L & Korentan \\
\hline $\mathrm{Q}_{\min }$ & $0 \mathrm{ml} / \mathrm{min}$ & $0.2 \mathrm{ml} / \mathrm{min}$ & $0.02 \mathrm{ml} / \mathrm{min}$ & $1 \mathrm{l} / \mathrm{s}$ \\
\hline $\mathrm{Q}_{\text {mean }}$ & $615 \mathrm{ml} / \mathrm{min}$ & $26 \mathrm{ml} / \mathrm{min}$ & $0.32 \mathrm{ml} / \mathrm{min}$ & $194 \mathrm{l} / \mathrm{s}$ \\
\hline $\mathrm{Q}_{\max }$ & $4,100 \mathrm{ml} / \mathrm{min}$ & $109 \mathrm{ml} / \mathrm{min}$ & $3.7 \mathrm{ml} / \mathrm{min}$ & $2,954 \mathrm{I} / \mathrm{s}$ \\
\hline $\mathrm{Q}_{\text {min }}: \mathrm{Q}_{\text {mean }}: \mathrm{Q}_{\max }$ & & 1:130:545 & 1:16:185 & 1:194:2954 \\
\hline Total outflow volume $\mathrm{Vt}\left(\mathrm{m}^{3}\right)$ & 304.5 & 12.6 & 0.16 & $5,752,203$ \\
\hline Volume of fast-flow $\mathrm{Vf}\left(\mathrm{m}^{3}\right)$ & 304.5 & 6.1 & 0.01 & $4,192,518$ \\
\hline Volume of base-flow $\mathrm{Vb}\left(\mathrm{m}^{3}\right)$ & 0 & 6.5 & 0.15 & $1,559,685$ \\
\hline Vf/Vt (\%) & 100 & 48 & 10 & 73 \\
\hline $\mathrm{Vb} / \mathrm{Vt}(\%)$ & 0 & 52 & 90 & 27 \\
\hline Effective infiltration (mm) & 1,242 & 1,242 & 1,242 & 998 \\
\hline Assessed extent of the catchment & $245 \mathrm{~m}^{2}$ & $10 \mathrm{~m}^{2}$ & $0.1 \mathrm{~m}^{2}$ & $5.8 \mathrm{~km}^{2}$ \\
\hline
\end{tabular}



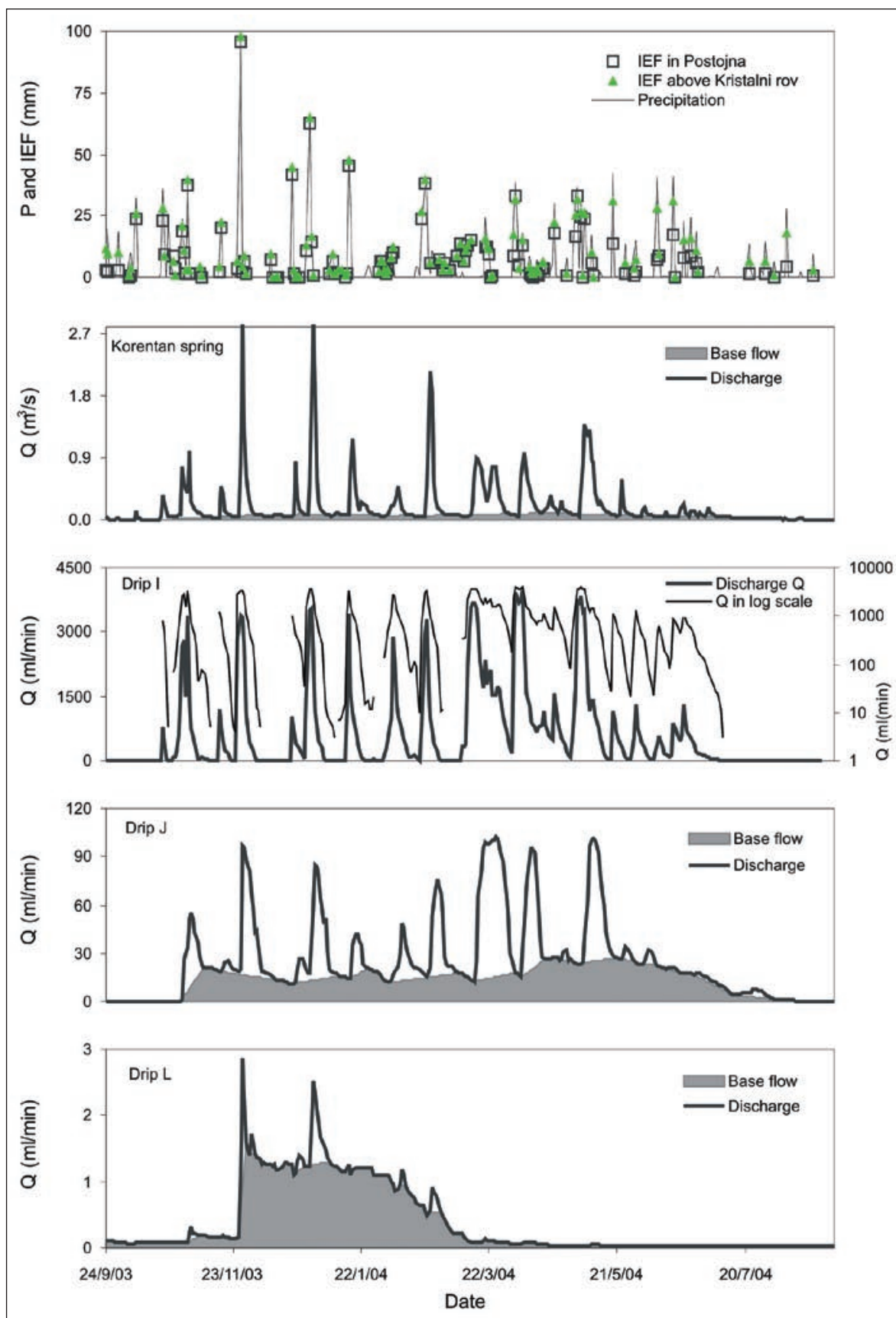

Fig. 2: Measured precipitation (P) and effective infiltration (IEF) at the two study areas, and discharges (Q) and base-flow of the Korentan spring and drips I, J and L.

the amount of surplus water, which actually recharges the karst aquifer. These basic relationships can be expressed using various more or less complex models, and we used the model developed within our study of the recharge-discharge characteristics in the catchment of the karst Vipava spring in southwestern Slovenia (Petrič 2002). Fig. 2 presents the comparison between measured precipitation and assessed effective infiltration. The distribution of days with recorded effective infiltration is practically the same for both study areas, but the amounts of infiltrated water are different due to different types of land use (forest covers $79 \%$ of the Korentan catchment, and 19\% of the surface above Kristalni rov). We should be aware of this difference (Tab. 1), but as we can assume that the functioning of karst systems is mainly influenced by the time distribution of the events with effective infiltration (and less by small differences in the amount of infiltrated water during individual events), we decided to proceed with the comparison of the characteristics of the Korentan spring and drips I, J, and L.

The characteristic discharges are presented in the upper part of Tab. 1. Longterm observations confirmed that $\mathrm{Q}$ of intermittent drip I increase to the maximum value and remain there for some time before starting to decrease (Figs. 2, 6, $7 \&$ 9). Although the recharge into the fissure increases, the flow through this fissure is limited, and the surplus water probably flows along other, unidentified channels. In comparison with drips I and J, drip L has smaller oscillations of Q; however, the ratio of 1:185 between minimum and maximum value is relatively high and to a certain degree reflects the karst nature of this drip. Its mean discharge varies significantly through the hydrological years (Fig. 4). The ratio between the mean discharges of drips L, J, and I is 1:81:1920, and of course the mean discharge of the Korentan spring is substantially higher. In our previous researches, drips with lower or higher $\mathrm{Q}$ then the ones included in detailed monitoring were observed also, but drips I, J, and L were selected as the most characteristic for the study area. 
Drip I reacts very rapidly to precipitation events with characteristic changes on a daily basis (Fig. 2). The other extreme is drip L with increased and steady $\mathrm{Q}$ over a period of several months, followed by a slow recession and then persistence at minimum Q values. Drip J is somewhere in between the two extremes. It reacts to individual precipitation events with high discharge peaks but with a certain time lag (several hours to several days) behind drip I. Water pulses produce less intensive oscillations of $\mathrm{Q}$ and have a longer duration.

The hydrographs of the Korentan spring and drip I had simultaneous peaks throughout the entire observation period, but the positions of the maximum values of $\mathrm{Q}$ were different (Fig. 2). During the wet autumn period, the reaction of the Korentan spring to precipitation events was very rapid and the maximum $Q$ was recorded. After only a short time lag, the discharge of drip I (after 3 hours) and drip J (after 10 hours) increased but did not reach their maximum values. In this wet autumn period, drip L had constantly high $\mathrm{Q}$ and the maximum values were reached. In contrast, during the dry spring and summer periods $\mathrm{Q}$ of drip $\mathrm{L}$ was near the minimum and the discharge peaks of the Korentan spring were also significantly lower while at the same time high peaks with maximum values were observed at drips I and J.

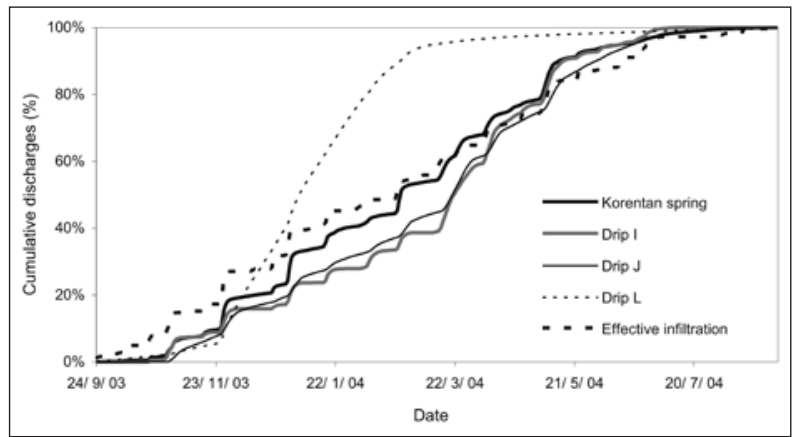

Fig. 3: Cumulative values of effective infiltration and discharges of the Korentan spring and drips I, J, and L.

Drip I with its maximum discharges in the spring period has different characteristics. It represents well permeable karst conduits that are only temporarily active. The water reserves in their catchments are small and can often be depleted in the time between two successive precipitation events. The discharge and its peak values are more dependent on momentary conditions and less on previous hydrological conditions.

To assess the differences in flow regimes at the monitoring points, the cumulative values of effective infiltration and discharge for the 2003-2004 hydrological year were compared (Fig. 3). The effective infiltration increases rather regularly through the entire hydrologi- cal year, which indicates a climate with relatively abundant precipitation distributed over the whole year. In the initial part, following a longer dry period at the end of the previous hydrological year, the reactions of $\mathrm{Q}$ to the infiltration were small. Only after heavy rain at the end of November 2003 did Q begin to increase more intensively. In the first half of the hydrological year, drip L had already reached $95 \%$ of its total outflow volume. It seems that in this period the cumulative curve of the Korentan spring was also more influenced by the constant recharge from the low-permeability zones. In the second part of the year, the impact of the preferential flow paths, characterized by higher $\mathrm{Q}$ of drip I, became more important (Fig. 3). Based on the comparison of the total amounts of effective infiltration and discharge in the 2003-2004 hydrological year, the extent of the recharge areas of the Korentan spring and the drips was assessed (Tab. 1). For the drips these catchments represent some fictive areas on the surface that drain toward them.

Additionally, the decomposition of hydrographs in the fast-flow and base-flow components was used for the comparison of the Korentan spring and the drips in the Kristalni rov passage. The base-flow is defined as the outflow of water that has been stored for a longer period of time in the low-permeability zones within the recharge

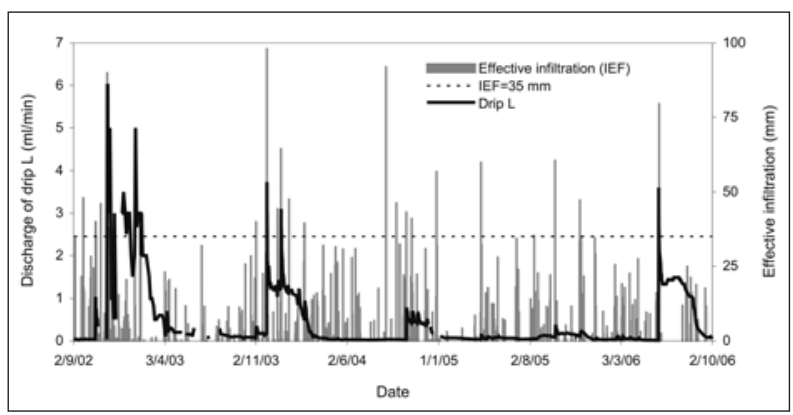

Fig. 4: Discharge of drip L and effective infiltration in the period from September 2, 2002, to October 2, 2006. The horizontal line borders the zone with daily values of effective infiltration below $35 \mathrm{~mm}$.

zone, whereas the fast-flow pertains to the reaction of discharge to the last precipitation event and the rapid transfer of a pressure pulse through more permeable karst conduits. The problems that may occur in applying this method are primarily due to the overlapping of the different effects of precipitation events and with the related difficulties in the assessment of the conditions in which only the base-flow exists. Various methods are used for the separation of base flow, and in our research we applied the method whereby a straight line is drawn between the point where the discharge starts to rise and 
the point where the discharge stops decreasing (Jeannin \& Grasso 1995).

The hydrographs with marked base-flow for the Korentan spring and the drips are presented in Fig. 2, and the proportions of fast-flow and base-flow in the observed hydrological year are shown in Tab. 1. We should specially mention drip I, for which the hydrograph is also drawn in semi-logarithmic scale. The form of this curve indicates that drip I is composed exclusively of the fast-flow component. The other extreme is drip L, where the base-flow dominates and only the most intensive precipitation events in wet periods lead to rapid and intensive reactions of Q. More than 70\% of fast-flow in the Korentan spring indicates that this spring drains a wellkarstified system with a significant proportion of karst conduits that allow the rapid transfer of water pulses through the system.

\section{CHARACTERISTICS OF DRIP L HYDROGRAPH OVER A LONGER PERIOD OF OBSERVATIONS}

Drip L, which represents the low-permeability flow paths within the observed system, was monitored over a longer time period from September 2002 to October 2006. The hydrographs for individual hydrological years differ significantly, and we therefore decided to compare and study them in more detail.

The discharge was compared with the effective infiltration (Fig. 4). A more detailed examination of the individual precipitation events revealed that two conditions must be fulfilled to stimulate higher Q. Only a combination of intensive precipitation events (according to our assessment based on daily values of effective infiltration above $35 \mathrm{~mm}$ ) and a high water saturation of the vadose zone results in higher base-flow and high discharge peaks. In a period of lower saturation of the vadose zone even after very intensive precipitation (for example on September 1, 2004, with a daily effective infiltration of $93 \mathrm{~mm}$ ), no significant increases in the hydrograph were observed. Similarly, when the saturation of the vadose zone is high, Q decreases if there are no intensive precipitation events (for example in March, 2004). Similar conditions were observed during all four hydrological years.

It is interesting that Q was the highest in the hydrological year 2002-2003 when the average daily precipitation of $3.2 \mathrm{~mm}$ was the lowest (the average precipitation was $5.2 \mathrm{~mm}$ in the 2000-2001 hydrological year, $3.8 \mathrm{~mm}$ in 2001-2002, $4.4 \mathrm{~mm}$ in 2003-2004, $4.1 \mathrm{~mm}$ in 20042005 , and $3.7 \mathrm{~mm}$ in 2005-2006). We can conclude that the conditions in previous years decisively influence the hydrological conditions and that the influence of dry and wet years applies over longer time periods. The distribution and frequency of intensive precipitation events also influence the characteristics and the form of the hydrographs.
Due to the lack of data, the effective infiltration was calculated only for the period from 2003 to 2006, and therefore the comparison with Q can only be done for these three hydrological years (Fig. 5).The total annual amount of effective infiltration decreased in successive hydrological years due to the lower amount of precipitation and higher evapotranspiration. The comparison with the total annual discharge of drips indicates the important influence of previously stored water over a time

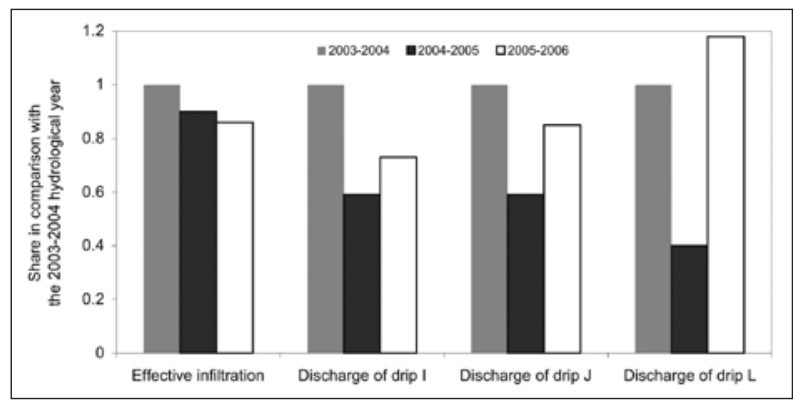

Fig. 5: Comparison of the annual amounts of effective infiltration and discharges of the drips for three successive hydrological years.

interval of one or several years. This is especially evident for drip L. In the 2004-2005 hydrological year, the total discharge was the lowest, even though the effective infiltration was only $10 \%$ lower than in the previous year. We can infer that the effective infiltration was mainly stored in the recharge area of the drip. In the following hydrological year, 2005-2006, Q was higher even though the effective infiltration was lower than in previous years. 


\section{COMPARISON OF THE REACTIONS OF DRIPS AND SPRING TO PRECIPITATION EVENTS}

EC in the spring and the drips was measured in addition to Q. The comparison of the obtained graphs indicates that for the selected monitoring points the characteristics of the reactions of the two parameters to individual precipitation events differ significantly. First a detailed analysis of 3 selected water pulses at different hydrological conditions is presented, and then based on an additional comparison of all nineteen water pulses in the hydrological year 2003-2004 some general characteristics are discussed.

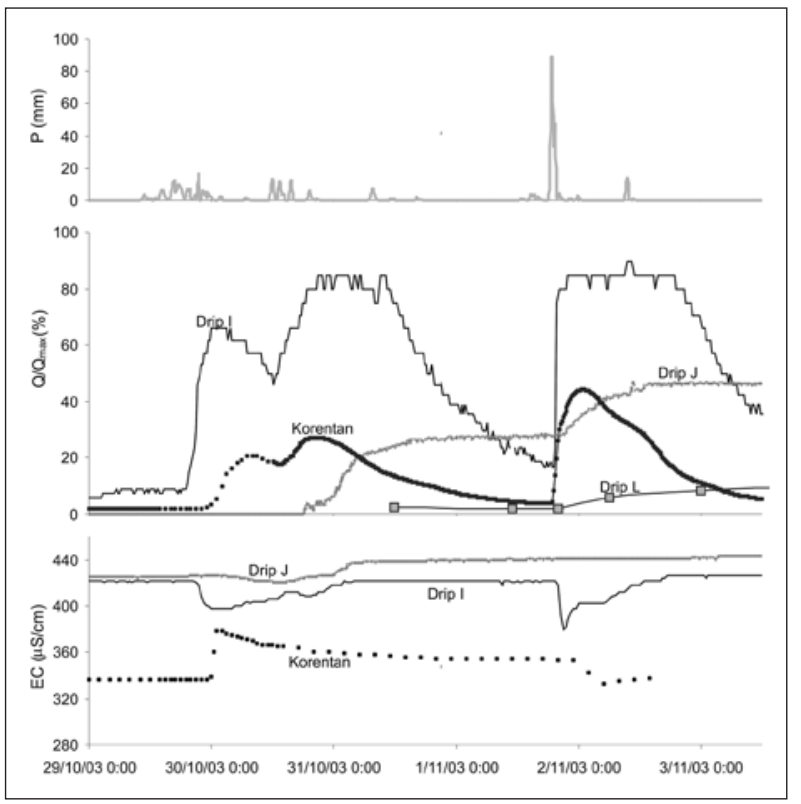

Fig. 6: Comparison of precipitation (P), discharges (Q), and conductivity (EC) of the Korentan spring and the drips in the Kristalni rov passage for the water pulse 1 (In Figs. 6, 7 \& 9 the discharges are presented relatively as a proportion of the maximum discharge at each monitoring point.).

\section{WATER PULSE 1 (END OF OCTOBER 2003 - BEGINNING OF NOVEMBER 2003)}

At the end of October 2003, a water pulse was generated when the saturation of the vadose zone was low following a longer dry period (Fig. 6). After an initial intensive precipitation event, $\mathrm{Q}$ of the Korentan spring and drip I reacted in few hours, and Q of drip J in two days after additional rain when a second pulse was recorded at the Korentan spring and drip I. Q at three of the monitoring points was relatively low and no change was observed in drip L. Due to the higher saturation, the reactions after the following precipitation event on November 2, 2003, were more rapid and intensive, and the Korentan spring and drip I responded to a new water pulse while the continuation of the first pulse was observed in drip J. A small reaction was also observed at drip L.

The practically simultaneous start of EC decrease with the start of Q increase in drip I indicates the influence of freshly infiltrated water. In drip J, EC started to

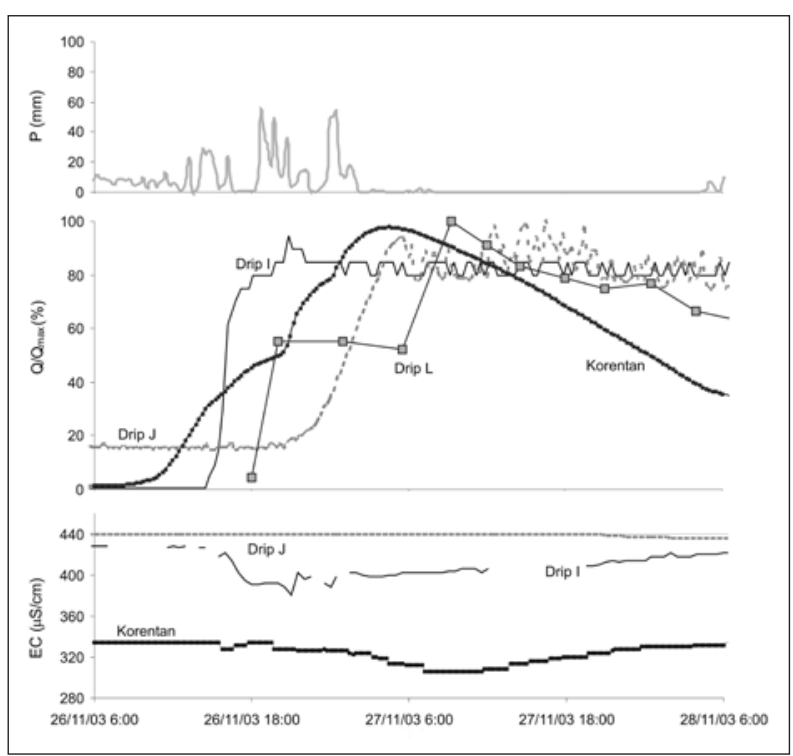

Fig. 7: Comparison of precipitation (P), discharges (Q), and conductivity (EC) of the Korentan spring and the drips in the Kristalni rov passage for the water pulse 2 (In Figs. 7 \& 9 a thin horizontal line is added to the EC curve of drip J in order to see the decrease of EC.).

increase in parallel with $\mathrm{Q}$, which indicates that the infiltrated precipitation pushed more mineralized water, previously stored in the epikarst zone, toward drip J.

\section{WATER PULSE 2 (END OF NOVEMBER 2003)}

The abundant precipitation throughout November 2003 resulted in a high water saturation of the vadose zone. After a very intensive precipitation event at the end of the month, the reactions of the Korentan spring and drip I were very rapid (within a few hours) and their peak discharges were very high (Fig. 7). Q of drips J and L started to increase within the same day. The sudden infiltration of precipitation into the highly saturated system placed pressure on the previously stored water and caused the rapid transfer of a pressure pulse through the vadose zone.

The characteristics of the "flow-through" process are indicated by the comparison of EC curves. In drip 
I the start of EC decrease was practically simultaneous with the start of Q increase, whereas in drip J the inflow of old water was first indicated by the unchanged values of EC and only after $\mathrm{Q}$ reached the maximum value did EC start to decrease slowly. Based on the comparison of measured Q, measured EC values, and presumed EC values of the precipitation and old water (for these values see the description of the calculation for the Korentan spring below), the proportion of freshly infiltrated water in drip I was assessed to be up to $13 \%$ of the total discharge. The reaction of discharge to the precipitation event was very fast and while the presence of freshly infiltrated water was detected almost immediately, mainly old water was flowing through drip I. We can infer that the precipitation that infiltrates into the epikarst zone of the catchment of the drips forces stored water toward the preferential flow paths and that within these the proportion of direct recharge from precipitation is relatively small.

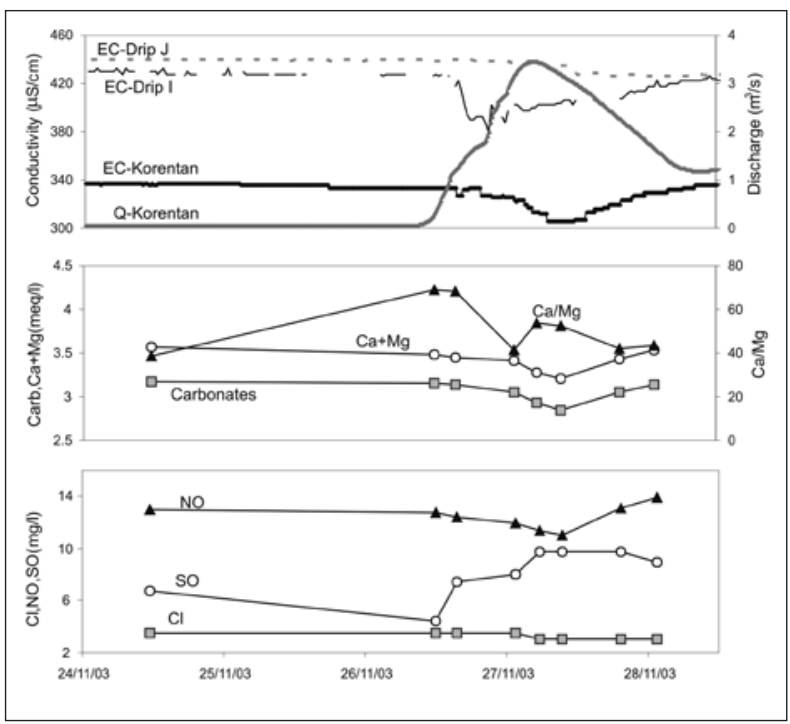

Fig. 8: Results of the chemical analysis of the Korentan spring during the water pulse at the end of November 2003 (Q-discharge, EC-conductivity, $\mathrm{Ca}+\mathrm{Mg}$-total hardness, NO-nitrates, SO-sulfates, Cl-chlorides).

EC of the Korentan spring first decreased slowly and then faster until it reached the minimum values after the peak discharge (Fig. 7). We can infer that the decrease of EC in the Korentan spring is primarily the result of the inflow through well permeable fissures (as with drip I; no change of EC was noticed in drip J during this event), and the contribution of more distant fissures is delayed. The influence of the sinking stream should be additionally considered. Based on the comparison of measured Q and EC, the joint contribution of freshly infiltrated water and water from the sinking stream during the peak of the water wave on November 27, 2003, was assessed at up to $10 \%$ of the total discharge. EC values of the Korentan spring were measured and based on these, a value was defined for old water $(336 \mu \mathrm{S} / \mathrm{cm})$. EC values of precipitation were measured in the Postojna area in a previous project over a period of two years (Kogovšek \& Kranjc, 1989 ), and the average value was assessed at $40 \mu \mathrm{S} / \mathrm{cm}$. However, if we take into account the fact that the freshly infiltrated water dissolves the carbonates along its path (EC assessed at $100 \mu \mathrm{S} / \mathrm{cm}$ ) and EC value of the sinking stream is $110 \mu \mathrm{S} / \mathrm{cm}$, the actual proportion of freshly infiltrated water is up to $13 \%$.

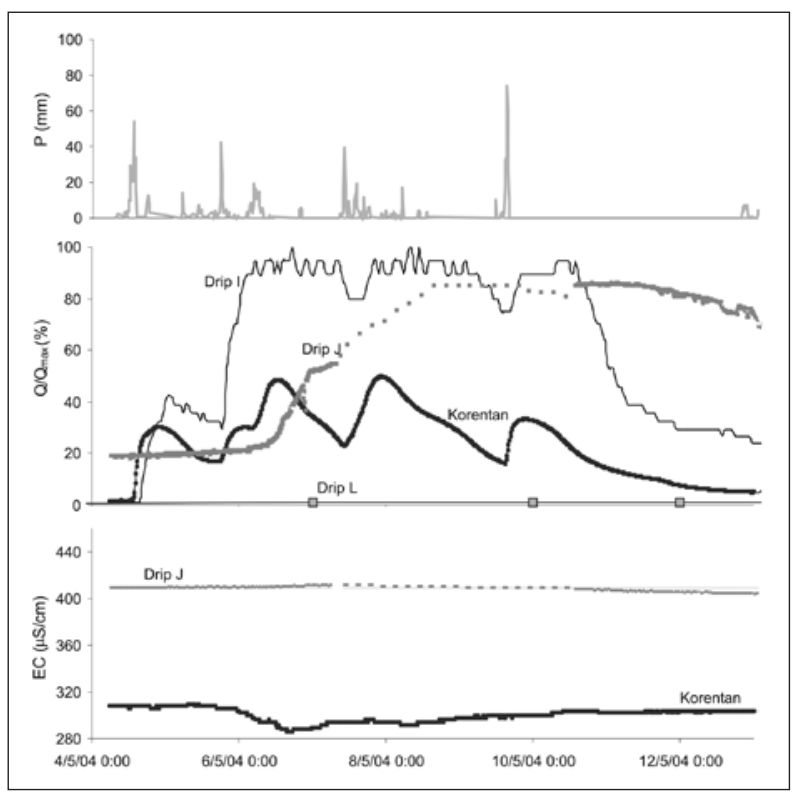

Fig. 9: Comparison of precipitation (P), discharges ( $Q)$, and conductivity (EC) of the Korentan spring and the drips in the Kristalni rov passage for the water pulse 3 .

During the water pulse at the end of November 2003, the chemical parameters (carbonates, total hardness, $\mathrm{Ca}$ / $\mathrm{Mg}$ ratio, chlorides, nitrates, sulfates, o-phosphates) were additionally measured at the Korentan spring (Fig. 8). The high ratio of $\mathrm{Ca} / \mathrm{Mg}(68)$ in the first part of the discharge increase indicates the inflow of old water previously stored in the vadose zone with a high $\mathrm{Ca} / \mathrm{Mg}$ ratio ( $\mathrm{Ca}$ and $\mathrm{Mg}$ are expressed in meq/l) The decrease of the $\mathrm{Ca} / \mathrm{Mg}$ ratio to 42 in the early morning of November 27,2003 , can be explained by the mainly inflow of water from the sinking Čermelice stream (its $\mathrm{Ca} / \mathrm{Mg}$ ratio was 13). As the sinking stream collects rainwater from the surface, the increase of its discharge following the precipitation event is very rapid. This water travels quickly from the ponor through the system of karst channels and recharges the spring in the initial phase of increase of the spring discharge. This results in significant changes of 
chemical parameters at the spring. The proportion of this allogenic recharge in the total spring discharge becomes soon insignificant (regarding the fact that this non-karst area covers only approximately $3 \%$ of the catchment) and the autogenic recharge through the vadose zone prevail. However, as only occasional measurements of the sinking stream are available, a more detailed assessment of its influence on the Korentan spring is not possible. The decrease of EC was simultaneous with the decrease of carbonates and total hardness, which indicates the inflow of less mineralized water along the preferential flow paths of the vadose zone (similar to drip I, where EC decreases synchronously with the increase of Q) and from the sinking stream. The concentrations of nitrates decreased similarly to the EC values, and the concentrations of sulfates increased in parallel with Q. Additional monitoring of longer duration would be necessary to study these relations in more detail. The changes in the concentrations of o-phosphates and chlorides were minimal.

\section{WATER PULSE 3 (BEGINNING OF MAY 2004)}

The conditions in the beginning of May 2004 were similar to those at the end of November 2003. After individual precipitation events, four water pulses were generated (Fig. 9). Between the peaks $\mathrm{Q}$ of the Korentan spring and drip I decreased only slightly and after a slight delay one continuous pulse was recorded at drip J. The precipitation was less intensive, and $\mathrm{Q}$ was therefore lower than during the event at the end of November 2003. At the time of the first, smaller peak at the Korentan spring, no changes of EC were observed. Only the more intensive increase of Q during the second pulse was followed by EC decrease. Its minimum value was reached after the peak of $Q$. The value then started to increase gradually and the following two $Q$ peaks had no significant effect on EC. We can infer that the sinking stream was active only for a shorter period and caused the minimum EC values of the Korentan spring approximately two days after the start of the first increase of Q. The initial decrease of EC was simultaneous with the intensive increase of $\mathrm{Q}$ in drip I, which indicates the influence of well permeable fissures in the vadose zone. In drip J, which has the characteristics of low-permeability flow paths, a small decrease of EC was observed only in the third water wave.

\section{GENERAL CHARACTERISTICS OF THE 2003-2004 HYDROLOGICAL YEAR}

In general we can conclude that the reaction times of $\mathrm{Q}$ of the Korentan spring and drip I are very similar (Figs. 2, $6,7 \& 9$ ). They both react within several hours, and it usually takes less than half a day after a rain for $Q$ to start increasing. It is difficult to define this time lag more precisely as it is partly a consequence of the processes that affect the precipitation in the air, vegetation, or soil and influence the amount of effective infiltration.

The time lag of drip $\mathrm{J}$ is a little longer and ranges from half a day to two days behind drip I (Figs. 2, 6, $7 \& 9$ ). It depends on the previous water saturation of the vadose zone and is shorter during periods of higher saturation. In the case of several successive precipitation events, the base-flow is higher. In the observed period, drip J reacted to almost every precipitation event, with the only exception in the conditions of very low waters at the end of the hydrological year when the infiltrated water was only stored and no outflow occurred (Fig. 10).

Drip L reacted to all precipitation events from October 2003 to March 2004 with time lags behind drip J (Figs. 2, 6, $7 \&$ 9). In this period the base-flow was high. From March 2004 no reactions were observed and Q was in recession.

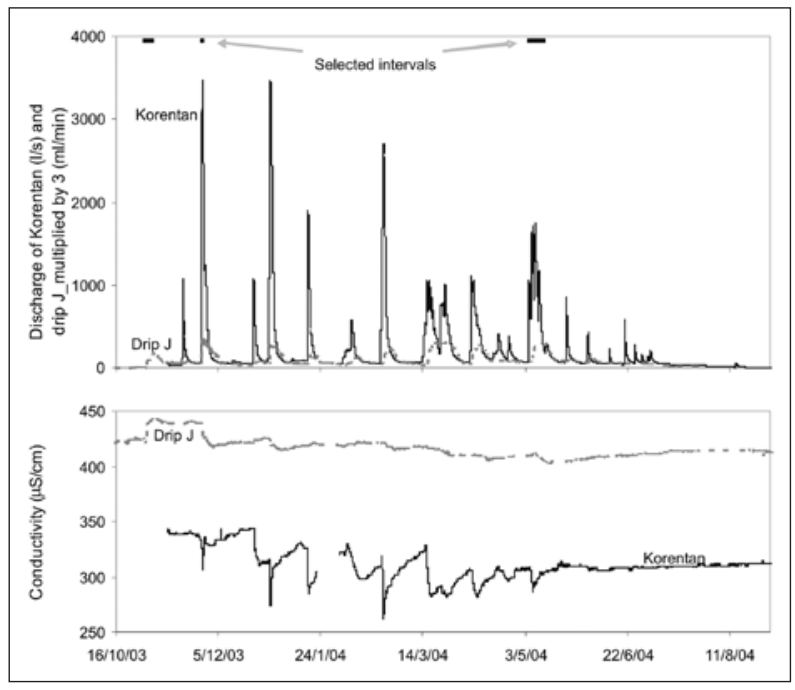

Fig. 10: Comparison of discharges and conductivity of the Korentan spring and drip J in the 2003-2004 hydrological year. The discharge of drip J is multiplied by 3. Selected individual water pulses are marked.

At all the monitoring points the increase of $\mathrm{Q}$ was accompanied by a decrease of EC, but with differences in the time lag and the intensity of the reaction (Figs. 6, $7 \& 9$ ). In the observed period of one hydrological year, the time lag of the reactions of EC behind Q at the Korentan spring was from half a day to one day and a half. In this time the so-called "old" water that was previously stored in the system is pushed out. The decrease of EC indicates the presence of freshly infiltrated water along with water from the sinking stream. In drip I, the reaction of EC is practically simultaneous with the change of Q. This indicates a very rapid inflow of freshly infiltrated water. The changes of EC in drip J are small and stretch 
over longer time intervals. Although the drip is influenced by freshly infiltrated water, the flow is significantly slower and retention time longer, which enables homog- enization and as a consequence smaller changes of EC of up to $10 \mu \mathrm{S} / \mathrm{cm}$ (Fig. 10). The decreases of EC in the Korentan spring and drip I are up to $50 \mu \mathrm{S} / \mathrm{cm}$.

\section{DISCUSSION}

The results of the comparison of hydrographs (Fig. 2) and especially the simultaneity of the maximum discharges of the Korentan spring with the high base-flow of drip $\mathrm{L}$ could be explained by the fact that water flowing from the low-permeability parts of the vadose zone (stored there after previous precipitation events and pushed out with sufficiently intensive effective infiltration during the observed event) contributes significantly to the recharge of the karst spring. Only in conditions of such high saturation of the vadose zone is the network of karst fissures hydraulically connected enabling the mobilization of water from all parts of the system. Similar conclusions can be drawn from the comparison of the cumulative curves (Fig. 3).

Long-term observations of drip L confirm that the amount of previously stored water is decisive for the reaction of low-permeability zones and that the influence of varying precipitation regimes applies over periods of one or even more years (Figs. $4 \& 5$ ). However, the significant influence of the distribution and frequency of intensive precipitation events is also evident.

Relatively rapid reactions of $\mathrm{Q}$ to precipitation events are characteristic for the entire system (Figs. 2, 6, 7 \& 9). The Korentan spring and drip I react almost simultaneously, usually less than half a day after a precipitation event. The time lag of drip J is longer and depends on the previous water saturation of the vadose zone; it can range from half a day to two days. The reaction of drip $L$ is the slowest and can even be negligible in dry periods.

The complex conditions of the water flow through the karst system are also indicated by the oscillations of EC and its characteristic decreases during the water pulses (Figs. 6, 7, $9 \& 10$ ). The almost simultaneous starts of Q increase and EC decrease in drip I reflect the inflow of freshly infiltrated water; however, the small changes of EC values show that its proportion is relatively small (to 13\%). Furthermore, the water that flows through the most permeable fissures is "old" water previously stored in the epikarst zone and pushed by freshly infiltrated water along preferential flow paths (drip I). In drips J and $\mathrm{L}$, the flow is slower and the retention time longer, and the changes of EC in drip J are smaller and gradual due to the homogenization of the water. The reactions at the Korentan spring reflect the existence of flow paths with various characteristics within the vadose zone of its recharge area. Infiltrated water from its more distant parts has a longer retention time and influences the outflow at the spring with a certain time lag. For a period of half a day to one and a half days after a precipitation event, old water flows through the spring and only then do the influences of the freshly infiltrated water and the sinking stream become noticeable. The reaction is faster in conditions of higher saturation of the vadose zone.

\section{CONCLUSIONS}

A detailed and long-term monitoring has proved to be a powerful tool in evaluating the influence and significance of processes within the vadose zone on the groundwater flow in karst systems and the functioning of karst springs. The long duration of the monitoring has provided data covering a more complete range of hydrological conditions and has enabled the assessment of the influences of preceding conditions. Furthermore, the high resolution of measurements at 15-minute intervals makes it possible to detect even the most rapid changes characteristic of karst water systems. An important advantage is being able to combine the information on various parameters obtained simultaneously at different monitoring points within the observed karst system and to compare the results.

The discharge of karst springs is induced by the inflow of water through a hierarchy of conduits of various permeabilities within the vadose zone, but especially important is the contribution of the stored water from lowpermeability parts. In conditions of high saturation of the vadose zone even the smaller fissures are filled with water, which enables a continuous hydraulic connec- 
tion of the fissures and an integral reaction of the entire drainage network within the vadose zone to the pressure pulses induced by infiltrated precipitation. We can infer that a dense network of small fissures contribute enough water to sustain high discharge and to balance the recharge inputs. On the other hand, the high-permeability fissures are recharged from the catchments with a lower storage capacity that still enable the rapid transfer of the input pulse toward the phreatic zone even in the periods of lower saturation of the vadose zone.

Long-term observations demonstrated that hydrological conditions in previous years significantly influence the process of outflow from the low-permeability zones. Therefore the momentary conditions and the reactions of discharge to precipitation events are the reflection of conditions over a longer period of several years.

\section{REFERENCES}

Bakalowicz, M., 1995: La zone d'infiltration des aquifères karstiques. Méthodes d'étude. Structure et fonctionnement.- Hydrogéologie, 4, 3-21.

Baker, A., Barnes, W.L. \& P.L. Smart, 1997: Variations in the discharge and organic matter content of stalagmite drip waters in Lower Cave, Bristol.- Hydrological Processes, 11, 1541-1555. DOI: 10.1002/ (SICI) 1099-1085(199709)11:11<1541::AID HYP484>3.0.CO;2-Z.

Bonacci, O. \& I. Andrić, 2010: Impact of an inter-basin water transfer and reservoir operation on a karst open streamflow hydrological regime: an example from the Dinaric karst (Croatia).- Hydrological Processes, 24, 3852-3863. DOI: 10.1002/hyp.7817.

Buser, S., Grad, K. \& M. Pleničar, 1967: Osnovna geološka karta SFRJ, list Postojna 1:100 000.- Beograd.

Čenčur Curk, B., Trček, B. \& M. Veselič, 2001: The study of solute transport with natural and artificial tracers at experimental field site Sinji Vrh.- RMZ - Materials and Geoenvironment, 48, 3, 401-413.

Fairchild, I.J., Tuckwell, G.W., Baker, A. \& A.F. Tooth, 2006: Modelling of dripwater hydrology and hydrochemistry in a weakly karstified aquifer (Bath, UK): Implications for climate change studies.- Journal of Hydrology, 321, 213-231. DOI:10.1016/j.jhydrol.2005.08.002.

Fernandez-Cortes, A., Calaforra, J.M., Sanchez-Martos, F. \& J. Gisbert, 2007: Stalactite drip rate variations controlled by air pressure changes: an example of non-linear infiltration processes in the 'Cueva del Agua' (Spain).- Hydrological Processes, 21, 920930. DOI: 10.1002/hyp.6283.

Gospodarič, R., Habe, F. \& P. Habič, 1970: The karst of Orehek and the source of the Korentan.- Acta Carsologica, 5, 95-108.

Groves, C., 2007: Hydrological methods.- In: Goldscheider, N. \& D. Drew (eds.) Methods in Karst Hydrogeology.Taylor \& Francis, pp. 45-64, London.
Jeannin, P.-Y. \& A.D. Grasso, 1995: Recharge respective des volumes de roche peu perméable et des conduits karstiques, rôle de l'épikarst.- Bulletin d'Hydrologie, 14, 95-111.

Jemcov, I. \& M. Petrič, 2010: Time series analysis, modelling and assessment of optimal exploitation of the Nemanja karst springs, Serbia.- Acta Carsologica, 39, 2, 187-200.

Jukić, D. \& V. Denić-Jukić, 2008: Estimating parameters of groundwater recharge model in frequency domain: Karst springs Jadro and Žrnovnica.- Hydrological Processes, 22, 4532-4542. DOI: 10.1002/ hyp.7057.

Kogovšek, J., 1997: Pollution transport in the vadose zone.- In: Günay, G., Johnson, A.I., Tezcan, L. \& A.Ö. Atilla (eds) Karst waters \& environmental impacts, Proceeding of $5^{\text {th }}$ international symposium and field seminar on karst waters and environmental impacts, $10^{\text {th }}-20^{\text {th }}$ September 1995, Antalya, Turkey. A.A.Balkema, 161-165, Rotterdam.

Kogovšek, J., 2000: How to determine the way of percolation and transport of substances by water tracing test in natural conditions.- Annales, 10, 1, 133-142.

Kogovšek, J., 2010: Characteristics of percolation through the karst vadose zone.- Založba ZRC SAZU, pp. 168, Postojna-Ljubljana.

Kogovšek, J. \& P. Habič, 1981: The study of vertical water percolation in the case of Planina and Postojna Caves.- Acta Carsologica, 9, 129-148.

Kogovšek, J. \& A. Kranjc, 1989: The influence of acid precipitations to processes in Postojnska jama.Acta Carsologica, 18, 221-232.

Kogovšek, J. \& S. Šebela, 2004: Water tracing through the vadose zone above Postojnska jama, Slovenia.- Environmental Geology, 45, 992-1001. DOI: 10.1007/ s00254-003-0958-z. 
Kogovšek, J. \& J. Urbanc, 2007: Estimation of percolating water dynamics through the vadose zone of the Postojna cave on the basis of isotope composition.Geologija, 50, 2, 477-486.

Kovačič, G., 2010: Hydrogeological study of the Malenščica karst spring (SW Slovenia) by means of a time series analysis.- Acta Carsologica, 39, 2, 201-215.

Lange, J., Arbel, Y., Grodek, T. \& N. Greenbaum, 2010: Water percolation process studies in a Mediterranean karst area.- Hydrological Processes, 24, 18661879. DOI: 10.1002/hyp.7624.

Maloszewski, P., Stichler, W., Zuber, A. \& D. Rank, 2002: Identifying the flow systems in a karstic-fissuredporous aquifer, Schneealpe, Austria, by modelling of environmental ${ }^{18} \mathrm{O}$ and ${ }^{3} \mathrm{H}$ isotopes.- Journal of Hydrology, 256, 48-59. DOI:10.1016/S00221694(01)00526-1.

Mangin, A., 1975: Contribution a l'étude hydrodynamique des aquiferes karstiques.- $\mathrm{PhD}$ thesis. Universite Dijon, pp.124.

McDonald, J. \& R. Drysdale, 2007: Hydrology of cave drip waters at varying bedrock depths from a karst system in southeastern Australia.- Hydrological Processes, 21, 1737-1748. DOI: 10.1002/hyp.6356.

Miorandi, R., Borsato, A., Frisia, S., Fairchild, I.J. \& D.K. Richter, 2010: Epikarst hydrology and implications for stalagmite capture of climate changes at Grotta di Ernesto (NE Italy): results from long-term monitoring.- Hydrological Processes, 24, 3101-3114. DOI: 10.1002 /hyp.7744.

Mudarra, M. \& B. Andreo, 2010: Hydrogeological functioning of a karst aquifer deduced from hydrochemical components and natural organic tracers present in spring waters. The case of Yedra spring (Southern Spain).- Acta Carsologica, 39, 2, 261-270.
Perrin, J., Jeannin, P.-Y. \& F. Zwahlen, 2003: Epikarst storage in a karst aquifer: a conceptual model based on isotopic data, Milandre test site, Switzerland.Journal of Hydrology, 279, 106-124. DOI:10.1016/ S0022-1694(03)00171-9.

Petrič, M., 2002: Characteristics of recharge-discharge relations in karst aquifer.- ZRC Publishing, pp. 154, Ljubljana.

Petrič, M. \& S. Šebela, 2004: Vulnerability mapping in the recharge area of the Korentan spring, Slovenia.Acta Carsologica, 33, 2, 151-168.

Pezdič, J., Leskovšek-Šefman, H., Dolenec, T. \& J. Urbanc, 1984: Isotopic study of karst water. Final Report on IAEA Research Contract No.2845/RB.- J.Stefan Institute, pp. 47, Ljubljana.

Standard Methods for Examination of Water and Wastewater $199218^{\text {th }}$ Edition. American Public Health Association: Washington.

Stichler, W., Trimborn, P., Maloszewski, P., Rank, D., Papesch, W. \& B. Reichert, 1997: Isotopic investigations.- Acta Carsologica, 26, 1, 213-235.

Trček, B., 2007: How can the epikarst zone influence the karst aquifer hydraulic behavior?- Environmental Geology, 51, 5, 761-765. DOI: 10.1007/s00254-0060387-x.

Vokal, B., Obelič, B., Genty, D. \& I. Kobal, 1999: Chemistry measurements of dripping water in Postojna Cave.- Acta Carsologica, 28, 1, 305-321.

Williams, P.W., 1983: The role of the subcutaneous zone in karst hydrology.- Journal of Hydrology, 61, 4567. DOI:10.1016/0022-1694(83)90234-2. 